\title{
HS 6-5-2 STEEL SURFACE LAYER DEVELOPMENT IN CARBONITRIDING WITH ZEROFLOW METHOD
}

\author{
Jerzy Jozwik, Krzysztof Dziedzic, Ireneusz, Usydus, Pero Raos, Grzegorz M. Krolczyk
}

Original scientific paper

The paper reviews the process of surface layer development with the use of carbonitriding and carbonitriding with oxidation. Employed for that purpose was a modern and ecological method called ZeroFlow. Research was carried out using HS 6-5-2 steel. Single-component nitrifying atmosphere of ammonia $\mathrm{NH}_{3}$ was applied. The temperature of the processes was $570{ }^{\circ} \mathrm{C}$. Diffusion layers were obtained on the steel. The thickness of the layers achieved during the microstructural research equalled from about $125 \mu \mathrm{m}$ after carbonitriding with oxidation to about $187 \mu \mathrm{m}$ after carbonitriding. Surface hardness $\mathrm{HV}_{1}$ was the highest for the carbonitrided layer - $1027 \mathrm{HV}_{1}$, whereas in the case of carbonitriding with oxidation it amounted to $1018 \mathrm{HV}$. As far as surface hardness $\mathrm{HV}_{30}$ is concerned, it was at the level of $813 \mathrm{HV}_{30}$ for the carbonitrided layer and $795 \mathrm{HV}_{30}$ for carbonitriding with oxidation. Surface hardness test results indicate surface layer hardening.

Keywords: carbonitriding; microhardness; nitriding; oxidation; surface layer

Dobivanje površinskog sloja HS 6-5-2 čelika karbonitriranjem uz primjenu metode ZeroFlow

Izvorni znanstveni članak

U radu se opisuje postupak dobivanja površinskog sloja primjenom karbonitriranja i karbonitriranja s oksidacijom uz pomoć suvremene i ekološke metode poznate kao ZeroFlow. Istraživanje je provedeno uporabom čelika HS 6-5-2. Primijenjena je jednokomponentna nitrificirajuća atmosfera amonijaka $\mathrm{NH}_{3}$. Postupak se vodio na temperaturi $570{ }^{\circ} \mathrm{C}$. Na čeliku su nastali difuzijski slojevi. Debljina slojeva dobivenih tijekom mikrostrukturnog istraživanja bila je od oko $125 \mu \mathrm{m}$ nakon karbonitriranja s oksidacijom do oko $187 \mu \mathrm{m}$ nakon karbonitriranja. Površinska hrapavost $\mathrm{HV}_{1}$ bila je najviša za karbonitrirani sloj $1027 \mathrm{HV}_{1}$, dok je u slučaju karbonitriranja s oksidacijom iznosila $1018 \mathrm{HV}_{1}$. Kad se radi o površinskoj tvrdoći HV nivou od $813 \mathrm{HV}_{30}$, a kod karbonitriranja s oksidacijom iznosila je $795 \mathrm{HV}_{30}$. Rezultati ispitivanja površinske tvrdoće ukazuju na otvrdnjavanje površinskog sloja.

Ključne riječi: površinski sloj; nitriranje; karbonitriranje; oksidacija; mikrotvrdoća

\section{Introduction}

One of the principal methods of surface integrity hardening encountered in industrial applications is thermochemical treatment $[1 \div 3]$. Obtaining the desired surface quality is a very important parameter for the functional maintenance of a part [4].The most hardened parts in industrial conditions are: drills, screw taps and dies [5]. What seems to be a common problem in industrial facility is how to increase the durability of the tools in use. Cutting tools and industrial blades can serve as an example [6]. From the production point of view, one of the fundamental criteria for tool selection is its operational durability, whose high level can be established by choosing suitable ways of its enhancement. The popularity of thermo-chemical treatment of steel through nitriding provoked a remarkable development of nitriding methods. Currently, there are various nitriding methods differing mainly in the ways of obtaining nitriding atmosphere and process parameters [7]. Another significant factor worth mentioning is the possibility to conduct nitriding with a simultaneous saturation with other chemical elements e.g. carbon [8]. Producing surface layers through a controlled gas carbonitriding with the use of a ZeroFlow method [9] is one of such methods. Development of new materials and their properties is important for the diagnostics of all machines [10].

ZeroFlow is a modern and ecological as well as less expensive method compared to other conventional nitriding processes [11]. What has been used most frequently in the existing methods of gas nitridning is a process based on controlled two-component atmospheres
- dissociated $\mathrm{NH}_{3}+\mathrm{NH}_{3}$ and $\mathrm{NH}_{3}+\mathrm{N}_{2}$. ZeroFlow is based on conducting a controlled nitriding process with the use of a single-component atmosphere in the form of ammonia $\mathrm{NH}_{3}$ which results in a reduction of process costs. First time this method was described by Małdzińskiet al. [12]. The processes of controlled gas nitriding are predominantly run in a two-step manner. The first one can be characterized by an intensive nitriding atmosphere, meaning a high nitriding potential, and is carried out at a lower temperature. In this stage a surface layer is saturated with nitrogen and a several-micrometerthick layer of iron nitride is developed. The second one takes place at a higher temperature, in a nitriding atmosphere of a lower intensity of nitriding. In this stage, the area of internal nitriding expands and a layer of iron nitride as well as a nitriding atmosphere serve as the source of nitrogen. At the same time, a slight increase of an iron nitride layer occurs at the surface $[13,14]$. In the ZeroFlow method, the regulation of an atmosphere chemical composition in a retort (regulation of a nitrogen potential) undergoes exclusively through the regulation of the intensity of ammonia flow through the retort. There are several advantages of the ZeroFlow method, which are minimum consumption of work gas and a simplified gas installation which have a positive influence on reducing the costs of its operation. During the nitriding process it is possible to saturate the surface with other chemical elements too. Carbonitriding with the use of the ZeroFlow method is based on simultaneous surface saturation with nitrogen and carbon. Applying ZeroFlow carbonitriding method in order to harden surface layers employed in a tool industry can have a positive influence on their costs and operational durability. 
ZeroFlow method of controlled nitriding and gas carbonitriding as well as carbonitriding with oxidation can be adopted in both laboratory and industrial environments. What is striven for in the case of tool steels and High Speed Steel (HSS) is obtaining a diffusion layer with the help of a nitriding method without or with a minimum thickness of an iron nitride surface layer [15]. The thickness of a surface layer usually amounts up to 0.3 $\mathrm{mm}[16]$.

The paper raises issues regarding hardening of a High Speed Steel HS 6-5-2 through the use of a controlled gas carbonitriding of the ZeroFlow method.

\section{Material and methods}

HS 6-5-2 steel was adopted as a research material. It is HSS applied for tools and machine parts with a dynamic load and operating in an elevated temperature. The chemical composition of HS 6-5-2 steel is shown in Tab. 1.

Table 1 Chemical composition of HS 6-5-2 steel / \%wt.

\begin{tabular}{|c|c|c|c|c|c|c|c|c|c|}
\hline $\mathrm{C}$ & $\mathrm{Si}$ & $\mathrm{Mn}$ & $\mathrm{Cr}$ & Mo & $\mathrm{Ni}$ & V & W & $\mathrm{S}$ & $\mathrm{P}$ \\
\hline 0,82 & Max & Max & 3,5 & 4,5 & Max & 1,7 & 6,0 & Max & $\operatorname{Max}$ \\
\hline $\begin{array}{c}\text { to } \\
0,92\end{array}$ & 0,5 & 0,4 & $\begin{array}{c}\text { to } \\
4,5\end{array}$ & $\begin{array}{c}\text { to } \\
5,5\end{array}$ & 0,4 & $\begin{array}{c}\text { to } \\
2,1\end{array}$ & $\begin{array}{c}\text { to } \\
7,0\end{array}$ & 0,03 & 0,03 \\
\hline
\end{tabular}

Applied processes of thermo-chemical treatment were carbonitriding and carbonitriding with oxidation. Research samples were cleaned in acetone. Carbonitriding and carbonitriding with oxidation were carried out with the use of a Seco/Warwick industrial oven for controlled ZeroFlow method gas nitriding with a possibility to control the parameters of the process such as its time, atmosphere, temperature and nitriding potential. They were monitored and recorded at every stage of the process. Control of a chemical composition of a nitriding atmosphere was carried out by means of periodic closing and opening inflows of ammonia $\mathrm{NH}_{3}$ and $\mathrm{CO}_{2}$ into a retort. The processes were led in a two-step manner. The maximum temperature was $570{ }^{\circ} \mathrm{C}$, the total time of the I and II stage equalled $360 \mathrm{~min}$., whereas nitriding potential amounted to 12 . Fig. 1 presents a multi-task and professional industrial station for nitriding with the use of the ZeroFlow method. Nitriding was conducted at The Center of Engineering Studies of The Institute of Technical Sciences and Aviation in The State School of Higher Education in Chełm.

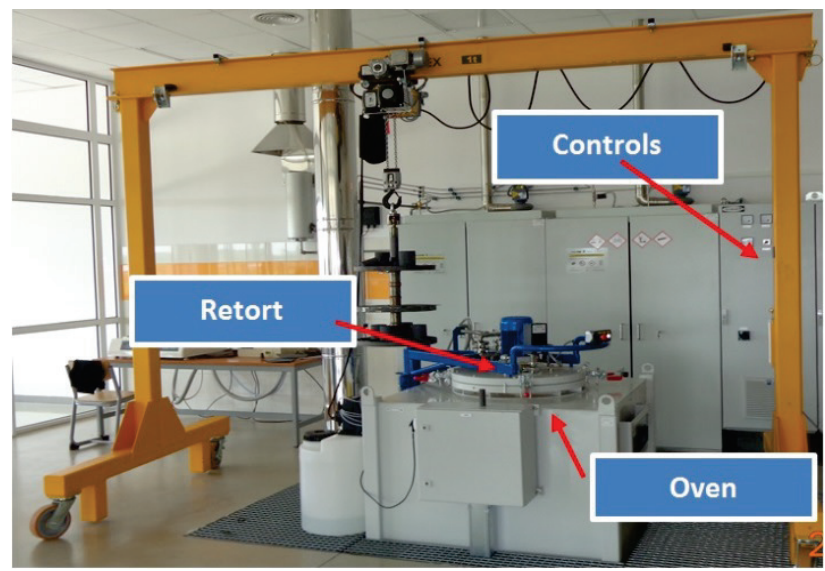

Figure 1 ZeroFlow method nitriding station
Obtained layers were characterised through analysing the microstructure, surface hardness and a hardness traverse of a surface layer. A device used for hardness study was a Wolpert-Wilson Tukon 2500 microhardness tester. Vickers method was applied. Surface hardness was determined for a load equalling $1 \mathrm{~kg}\left(\mathrm{HV}_{1}\right)$ and $30 \mathrm{~kg}$ $\left(\mathrm{HV}_{30}\right)$. Measurements were performed in various areas of the analysed layers. Measurement results represent average values obtained from 30 measurements carried out on a surface of an analysed sample after a suitable process of thermo-chemical treatment. Hardness traverse of a surface layer was measured for a load at the level of $0,5 \mathrm{~kg}\left(\mathrm{HV}_{0,5}\right)$. The samples were prepared using standard metallographic techniques [17] by grinding, polishing, and etching. A device adopted for the purpose of a microstructural research was Nikon Eclipse MA 200. The focus of the observation was the thickness of the layers in cross section of the samples. The samples are presented in Fig. 2.
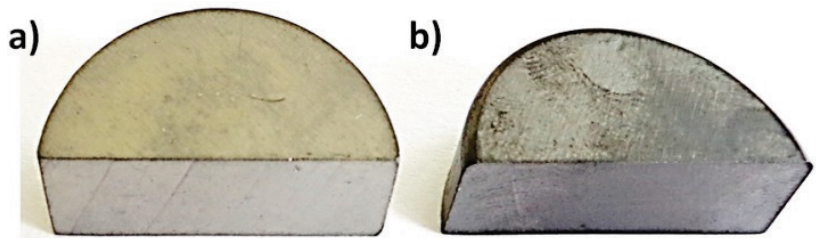

Figure 2 The view of the samples: a) after carbonitriding, b) after carbonitriding with oxidation

\section{Discussion}

Regulating growth kinetics of the layers was conducted by controlling the parameters of the process. HS 6-5-2 steel was subject to carbonitriding and carbonitriding with oxidation according to the parameters presented in Tab. 2. For every procedure, the temperature, time and a nitriding potential were provided. Programmed nitriding time was 8,35 hours after carbonitriding and 9,47 hours after carbonitriding with oxidation. The overall duration of the processes (heating, (reaching), warming (in the air, in nitrogen), nitriding, nitrogen purging and cooling) was higher and equalled 18 hours after carbonitriding and 15 hours after carbonitriding with oxidation. The temperature of the first stage was $490{ }^{\circ} \mathrm{C}$ in the time of 60 minutes. Its nitriding potential was 12 . In the case of the second stage, the temperature reached 570 ${ }^{\circ} \mathrm{C}$, the time of the process was $300 \mathrm{~min}$. and its nitriding potential 1 .

After carbonitriding of HS 6-5-2 steel, the properties of the obtained layers were analysed. What happens as a result of carbonitriding and carbonitriding with oxidation is a considerable hardening and a beneficial change in mechanical properties of HS 6-5-2 steel. The evaluation of HS 6-5-2 surface hardness was carried out with the help of two loads $-1 \mathrm{~kg}\left(\mathrm{HV}_{1}\right)$ and $30 \mathrm{~kg}\left(\mathrm{HV}_{30}\right)$. Surface hardness $\mathrm{HV}_{1}$ was the highest for a carbonitrided layer and it equalled $1027 \mathrm{HV}_{1}$. The layer which was subjected to carbonitriding with oxidation had a slightly lower surface hardness amounting to $1018 \mathrm{HV}_{1}$. A similar situation could be observed in the case of surface hardness $\mathrm{HV}_{30}$. After carbonitriding, it was $813 \mathrm{HV}_{30}$, whereas after carbonitriding with oxidation - $795 \mathrm{HV}_{30}$. Having determined surface hardness, the thickness of the 
obtained layers was examined. For that purpose, hardness traverse of a surface layer was studied and microstructural tests were carried out. Hardness examination was performed with the use of the Vickers method under the load of $0,5 \mathrm{~kg}\left(\mathrm{HV}_{0,5}\right)$. Hardness traverse of proper layers was examined five times. Results are presented in Fig. 3. Hardness profiles constitute average values obtained for every sample.

Table 2 The parameters of the process of controlled carbonitriding and carbonitriding with oxidation with the use of the ZeroFlow method
\begin{tabular}{|c|c|c|c|c|c|c|c|}
\hline \multirow{2}{*}{$\begin{array}{c}\text { Item } \\
\text { number }\end{array}$} & \multirow{2}{*}{ Procedure } & \multicolumn{3}{c|}{ Carbonitriding } & \multicolumn{3}{c|}{ Carbonitriding with oxidation } \\
\cline { 3 - 9 } & & Temp. & Duration & $\begin{array}{c}\text { Order } \\
\text { no. }\end{array}$ & Temp. & Duration & Order no. \\
\cline { 3 - 9 } & & ${ }^{\circ} \mathrm{C}$ & Min. & - & ${ }^{\circ} \mathrm{C}$ & Min. & - \\
\hline 1 & ONE-GAS NITRIDING & 490 & 60 & 12 & 490 & 60 & 12 \\
\hline 2 & TWO-GAS NITRIDING & 570 & 300 & 1 & 570 & 300 & 1 \\
\hline 3 & NITROGEN PURGING WITH WARMING* & - & - & - & 520 & 30 & - \\
\hline 4 & WATER OXIDATION* & - & - & - & 520 & 2 & - \\
\hline 5 & WATER OXIDATION* & - & - & - & 520 & 40 & - \\
\hline
\end{tabular}

* procedures for carbonitriding with oxidation

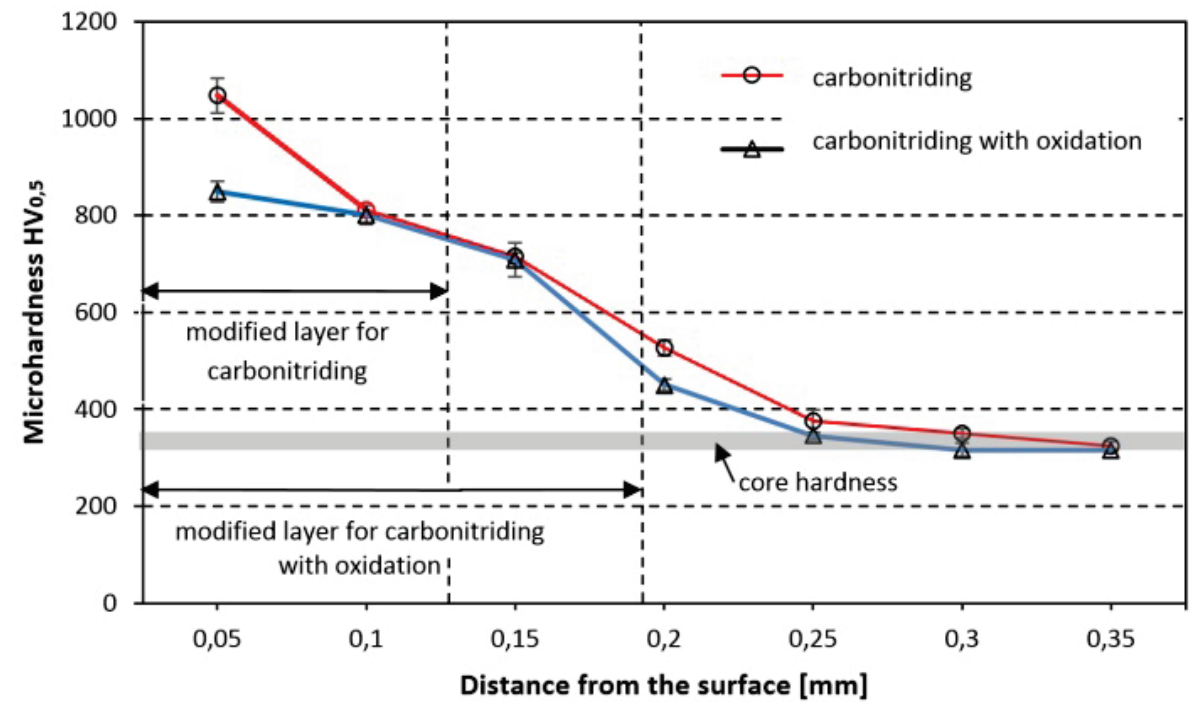

Figure 3 Hardness profiles for HS 6-5-2 steel

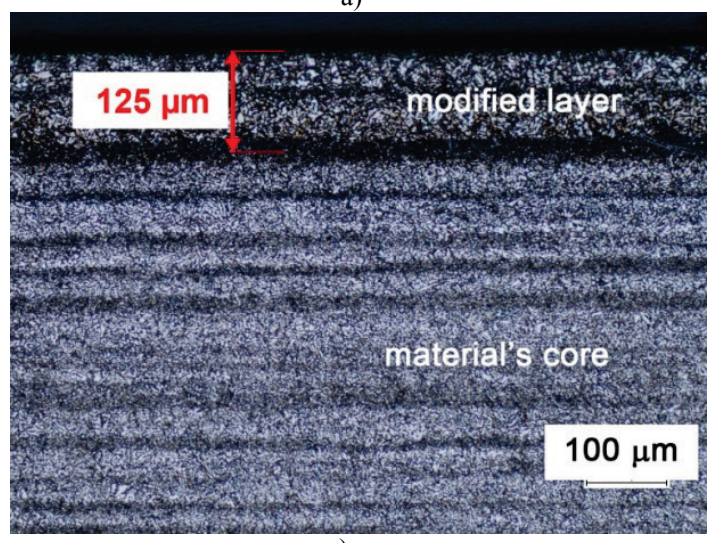

c)

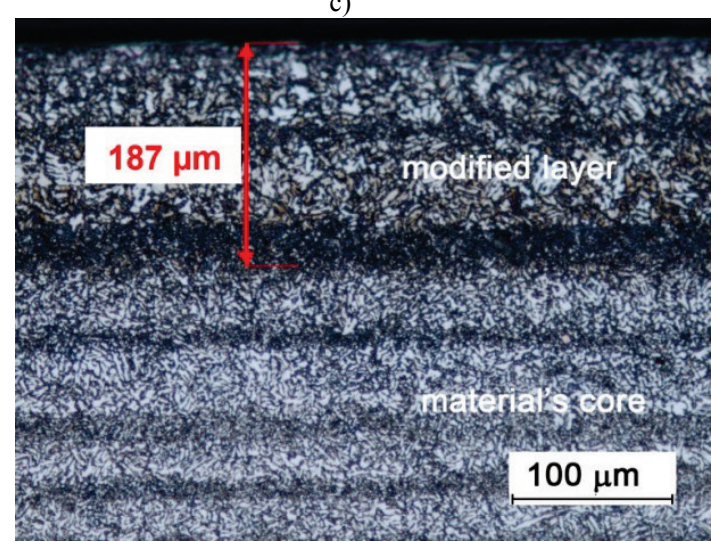

b)

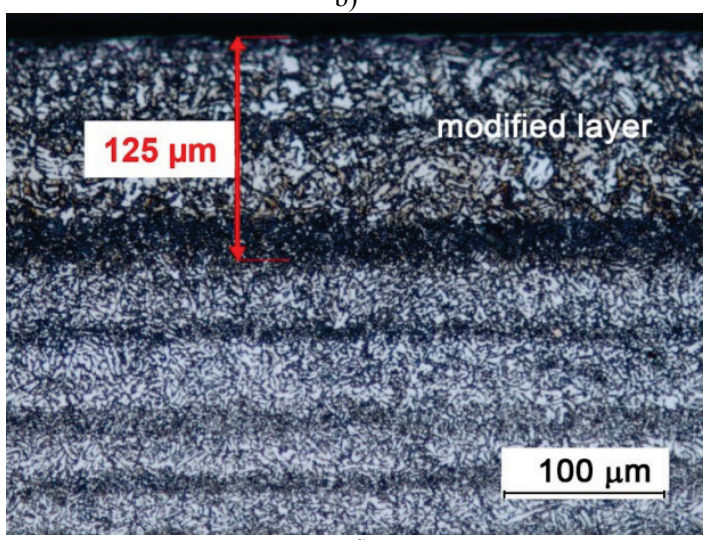

d)

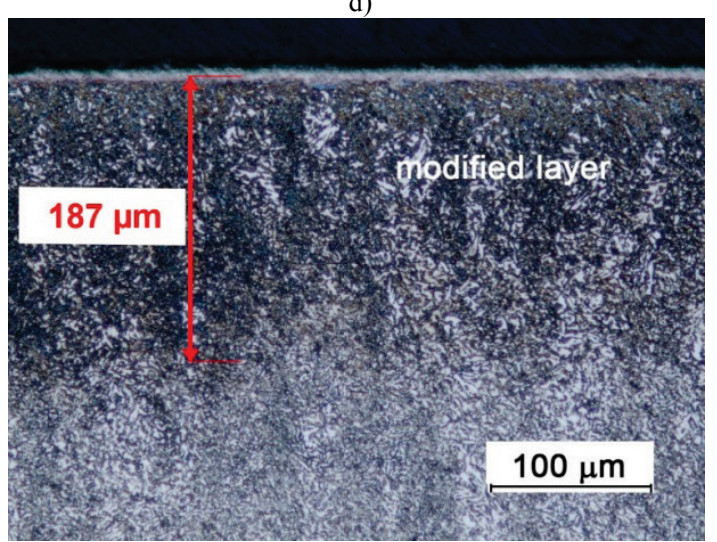

Figure 4 HS 6-5-2 steel diffusion layer thickness values: a, b) after carbonitriding, c, d) after carbonitriding with oxidation (magn. $\times 200$ ) 
Core hardness of the HS 6-5-2 steel samples under examination was $350 \mathrm{HV}_{0,5}$. Applying layer thickness criterion, which was core hardness $+50 \mathrm{HV}_{0,5}$, the thickness of all the obtained diffusion layers equalled about $0,25 \mathrm{~mm}$. The highest thickness amounting to 1048 $\mathrm{HV}_{0,5}$ was at the depth of $0,05 \mathrm{~mm}$. It was lower for the layer subjected to carbonitriding with oxidation - 838 $\mathrm{HV}_{0,5}$. What served as a verification of the achieved results was a microstructural research. Diffusion layer thickness values after carbonitriding and carbonitriding with oxidation are presented in Fig. 4.

What was observed while analysing research results is that the thickness of a layer after carbonitriding was about $125 \mu \mathrm{m}$ (Fig. 4a), whereas the thickness of a diffusion layer after carbonitriding with oxidation was approximately $187 \mu \mathrm{m}$ (Fig. 4c). As a result of the undertaken research, relatively even hardened surface layers were obtained. A thin surface layer of iron nitride was observed in the pictures, constituting so-called "white layer" whose thickness was ranging from a few to several $\mu \mathrm{m}$ (Fig. 4b, d). The white layer was more distinctive in the case of carbonitriding with oxidation (Fig. 4d)

\section{Conclusions}

The results obtained show that there is the possibility to apply carbonitriding and carbonitriding with oxidation with the use of the ZeroFlow method in order to develop properties of a technological surface layer on a HS 6-5-2 High Speed Steel. As a result of the conducted research the following final conclusions can be drawn:

1) Relatively even and repetitive surface layer hardness values were obtained for the following processes: carbonitriding and carbonitriding with oxidation.

2) Thickness values of the layers obtained during the microstructural research varied from about $125 \mu \mathrm{m}$ after carbonitriding with oxidation to about $187 \mu \mathrm{m}$ after carbonitriding.

3) As to the layer thickness criterion which is core hardness $+50 \mathrm{HV}_{0,5}$, the thickness of the obtained diffusion layers equalled about $0,25 \mathrm{~mm}$.

4) Surface hardness $\mathrm{HV}_{1}$ was the highest for a carbonitrided layer $\left(1027 \mathrm{HV}_{1}\right)$, it was $1018 \mathrm{HV}_{1}$ as far as carbonitriding with oxidation is concerned. As for surface hardness $\mathrm{HV}_{30}$, it was at the level of 813 $\mathrm{HV}_{30}$ for a carbonitrided layer and $795 \mathrm{HV}_{30}$ for a layer after carbonitriding with oxidation.

5) Having analysed research results, it can be stated that the hardening of a surface layer of HS 6-5-2 High Speed Steel with the use of controlled gas carbonitriding as well as carbonitriding with oxidation where ZeroFlow method is applied is highly advantageous. Layers obtained in such a way have a considerable potential in a wide range of applications. The main benefit resulting from their use is the improvement of mechanical properties of machine and tool parts made of HS 6-5-2 steel.

This project and its results also established the basis for further studies of surface integrity after thermochemical treatment and the relation of technological parameters to surface properties.

\section{References}

[1] Maruda, R.; Legutko, S.; Krolczyk, G.; Hloch, S.; Michalski, M. An Influence of Active Additives on the Formation of Selected Indicators of the Condition of the Z10CrNi18-8 Stainless Steel Surface Layer in MQCL Conditions. // International Journal of Surface Science and Engineering. 9, 5(2015), pp. 452-465. DOl: 10.1504/IJSURFSE.2015.072069

[2] Ruggiero, A.; Merola, M.;Carlone, P.;Archodoulaki, V.-M. Tribo-mechanical characterization of reinforced epoxy resin under dry and lubricated contact conditions. // Composites Part B: Engineering. 79 (2015), pp. 595-603. DOl: 10.1016/j.compositesb.2015.05.015

[3] Zebala, W.; Kowalczyk, R. Estimating the effect of cutting data on surface roughness and cutting force during WC-Co turning with PCD tool using Taguchi design and ANOVA analysis. // The International Journal of Advanced Manufacturing Technology. 77 (2015), pp. 2241-2256. DOI: 10.1007/s00170-014-6382-6

[4] Hreha, P.; Radvanska, A.; Knapcíkova, L.; Krolczyk, G. M.; Legutko, S.; Krolczyk, J.; Hloch, S.; Monka, P. Roughness parameters calculation by means on-line vibration monitoring emerging from AWJ interaction with material. // Metrology and Measurement Systems. XXII, 2(2015), pp. 315-326. DOI: 10.1515/mms-2015-0024

[5] Mittemeijer, E. J.; Somers, M. Thermochemical Surface Engineering of Steels. Woodhead Publishing 2014.

[6] Pashechko, M.; Dziedzic, K.; Barszcz, M. Study of the structure and properties of wear-resistant eutectic Fe-Mn-CB-Si-Ni-Cr coatings. // Powder metallurgy and metal ceramics. 7-8, 52(2013), pp. 469-476. DOI: 10.1007/s11106013-9549-z

[7] Wach, P.; Michalski, J.; Tacikowski, J.; Kowalski, S.; Betiuk, M. Gazowe azotowanie i jego odmiany w przemysłowych zastosowaniach. // Inżynieria materiałowa. 6 (2008), pp. 808-811.

[8] Blicharski, M. Inżynieria Powierzchni, WNT, Warszawa 2009.

[9] Małdziński, L.; Tacikowski, J.; Bazel, M.; Korecki, M.; Miliszewski, A.; Przygoński, T. Przemysłowe zastosowania azotowania gazowego metodą ZeroFlow. // Inżynieria Powierzchni. 3(2010), pp. 48-53.

[10] Glowacz, A.; Glowacz, A.; Glowacz, Z. Recognition of Thermal Images of Direct Current Motor with Application of Area Perimeter Vector and Bayes Classifier. // Measurement Science Review. 15, 3(2015), pp. 119-126. DOI: $10.1515 / \mathrm{msr}-2015-0018$

[11] Małdziński, L.; Tacikowski, J. Regulowane azotowanie gazowe $\mathrm{z}$ oszczędnym wykorzystaniem amoniaku. // Inżynieria Powierzchni. 4(2006), pp. 9-21.

[12] Małdziński, L.; Liliental, W.; Tymowski, G.; Tacikowski, J. New Possibilities of Controlling the Gas Nitriding Process by Utilizing Simulation of Growth Kinetics of Nitride Layer. // Surface Engineering. 15, 5(1999), pp. 377-384. DOI: 10.1179/026708499101516740

[13] Zyśk, J. Rozwój azotowania gazowego stopów żelaza, Wydawnictwo Instytutu Mechaniki Precyzyjnej, Warszawa 2008.

[14] Michalski, J. Charakterystyki i obliczenia atmosfer do regulowanego azotowania gazowego stali, Wydawnictwo Instytutu Mechaniki Precyzyjnej, Warszawa 2011.

[15] Fares, M. L.; Talhi, A.; Chaoui, K.; Touhami, M. Z.; Effects of gas carbonitriding process on surface characteristics of new hot working tool steel. // Surface Engineering. 27, 8(2011), pp. 595-601. DOI: 10.1179/026708410X12786785573157

[16] Michalski, J.; Tacikowski, J.; Wach, P.; Ratajski, J.; Mońka, G.; Nakonieczny, A. Azotowanie gazowe stali 
stopowych z i bez przypowierzchniowej warstwy azotków żelaza. // Inżynieria materiałowa. 4(2010), pp. 1100-1103.

[17] Krolczyk, G.; Legutko, S.; Nieslony, P.; Gajek, M. Study of the surface integrity microhardness of austenitic stainless steel after turning. // Tehnički vjesnik-Technical Gazette, 21, 6(2014), pp. 1307-1311.

\section{Authors' addresses}

Jerzy Jozwik,

Mechanical Engineering Faculty,

Lublin University of Technology,

Nadbystrzycka Street, 36, 20-618 Lublin, Poland

E-mail: j.jozwik@pollub.pl

Krzysztof Dziedzic,

Fundamentals of Technology Faculty,

Lublin University of Technology,

Nadbystrzycka Street, 36, 20-618 Lublin, Poland

E-mail: k.dziedzic@pollub.pl

\section{Ireneusz Usydus,}

The Institute of Technical Sciences and Aviation,

The State School of Higher Education,

Pocztowa Street, 54, 22-100 Chelm, Poland

E-mail: iusydus@pwsz.chelm.pl

\section{Pero Raos,}

J. J. Strossmayer University of Osijek,

Mechanical Engineering Faculty in Slavonski Brod,

Trg Ivane Brlić-Mažuranić 2

35000 Slavonski Brod, Croatia

E-mail: praos@sfsb.hr

\section{Grzegorz M. Krolczyk}

Opole University of Technology,

76 Prószkowska Street, 45-758 Opole, Poland

E-mail: g.krolczyk@po.opole.pl 